\title{
Ancestral heritage of flood plain residence and solid waste disposal pattern in flood events in Kogi State, Nigeria
}

\author{
O. M. Aderoju ${ }^{1,2}$, A. Guerner Dias ${ }^{1} \&$ B. Anwasia ${ }^{1}$ \\ ${ }^{1}$ Faculty of Sciences, University of Porto, Portugal \\ ${ }^{2}$ National Space Research and Development Agency (NASRDA), Nigeria
}

\begin{abstract}
The 2012 flooding incidents in Nigeria claimed lives and properties, rendered many homeless and also interrupted the development of the environment and socio-economic activities. High poverty levels, unethical waste disposal methods and strong affinity to flood plains for economic survival by communities in claims to ancestral credence have contributed immensely to flood disaster in Kogi State, Nigeria. In a way to attenuate the damage extent and causalities recorded from flooding in the past, this study aims at sensitizing the citizens on environmental ethics as a risk to flooding and generating a flood vulnerability map to identify communities at flood plain in Kogi State. The methodology adopted the Aderoju Conceptual Model (ACM) of environmental ethics and discipline on solid waste management. Also, Geographic Information Systems (GIS) was employed to identify and map out the communities in flood plains. It was deduced that over 73 communities from 7 local government areas (LGA) namely Lokoja, Kotokarfi, Bassa, Ajaokuta, Ofu, Idah and Ibaji in Kogi State are susceptible to flooding. From vulnerability map, safe zones closer to their source of livelihood for communities were identified. Government policies and intervention towards poverty alleviation as well as environmental awareness for the inhabitants in Kogi State will educate and build their conscious mind towards a friendly and sustainable solid waste disposal ethics regarding flood risk mitigation in the society.
\end{abstract}

Keywords: floodplains, flooding, municipal solid waste (MSW), GIS, vulnerability. 


\section{Introduction}

The action of man and his beliefs has contributed immensely to the high record of losses in any flood event. Flooding, one of the most frequent and widespread of all environmental hazards and of various types and magnitudes, occurs in most terrestrial portions of the globe, causing huge annual losses in terms of damage and disruption to economic livelihoods, businesses, infrastructure, services and public health [1]. Within a span of 10 years - from 1993 to $2002-$ the International Federation of Red Cross and Red Crescent Societies (IFRC) [2] reported that flood disasters affected more people across the globe (140 million per year on average) than all the other natural or technological disasters put together. According to the European Commission [3], flood can be defined as a natural phenomenon that results in the temporary submerging with water of a land that does not occur under natural conditions. Flooding in urban areas is seriously becoming an ecological menace in Nigeria as several coastal areas along the Atlantic Ocean, surrounding cities and river valleys are affected by flooding on a yearly basis [4]. Flash floods are the most common in Nigeria during the peak of the rainy season (June-October). The 2012 flood event in Nigeria is described as the worst in recent times. The 2012 flood, had a devastating effect on the country, especially states along the rivers Niger and Benue with huge destruction to the rural and urban infrastructure (farmlands/ crops, roads, buildings, drainages, bridges, power lines etc.) and the socioeconomic lives of the area [5]. Kogi State was the most affected state due to its location at the confluence of the country's major rivers (Niger-Benue Rivers). The experience in Kogi State during the flood disaster in 2012 was beyond description which attracted humanitarian assistance from the National Emergency Management Agency (NEMA), International Federation of Red Cross and Red Crescent Societies (IFRC), the World Bank and many among others. This led to most settlements being inundated, rendering thousands of people homeless, destroyed thousands of hectares of farmland and livestock and also loss of aquatic animals [6]. The obvious reasons for flooding especially in municipalities and coastal areas in Nigeria are: the attraction of human settlements to low-lying coastal areas and river flood plains due to fertility or ancestral home, poor drainage system and blocked existing drainage with municipal waste, refuses and eroded soil sediments [7-9]. Geographic Information System (GIS) is widely used to analyze natural hazards such as landslides, flooding, among others. Geographic Information System (GIS) can simply be defined as an informative system that can identify, store, analyze, manipulate and retrieval of geographically referenced data. The high level of poverty, unethical waste disposal methods and strong affinity to flood plains for economic survival by communities in claims to ancestral credence have contributed immensely to flood disaster in Kogi State, Nigeria. In a way to attenuate the damage extent and causalities recorded from flooding in the past, this study aims at identifying and map out vulnerable communities at the flood plain in Kogi State, and also to sensitize the citizens on environmental ethics on improper solid waste disposal pattern as a risk to possible flooding. 


\subsection{Study area}

Kogi State can be found in the central region of Nigeria, located between latitudes $6^{\circ} 30^{\prime} \mathrm{N}$ and $8^{\circ} 50^{\prime} \mathrm{N}$, and longitudes $5^{\circ} 51^{\prime} \mathrm{E}$ and $8^{\circ} 00^{\prime} \mathrm{E}$ with a total land area of $29,833 \mathrm{~km}^{2}$ and a population of $3,841,884$ with a growth rate of $3 \%$ [10]. Kogi State is popularly called the confluence state because of the confluence of River Niger and River Benue at its capital (Lokoja). Lokoja was the first administrative capital of modern-day Nigeria. The state was formed in 1991 from parts of Kwara State and Benue State. The state was as presently constituted, comprises the people of the defunct Kabba province of Northern Nigeria.

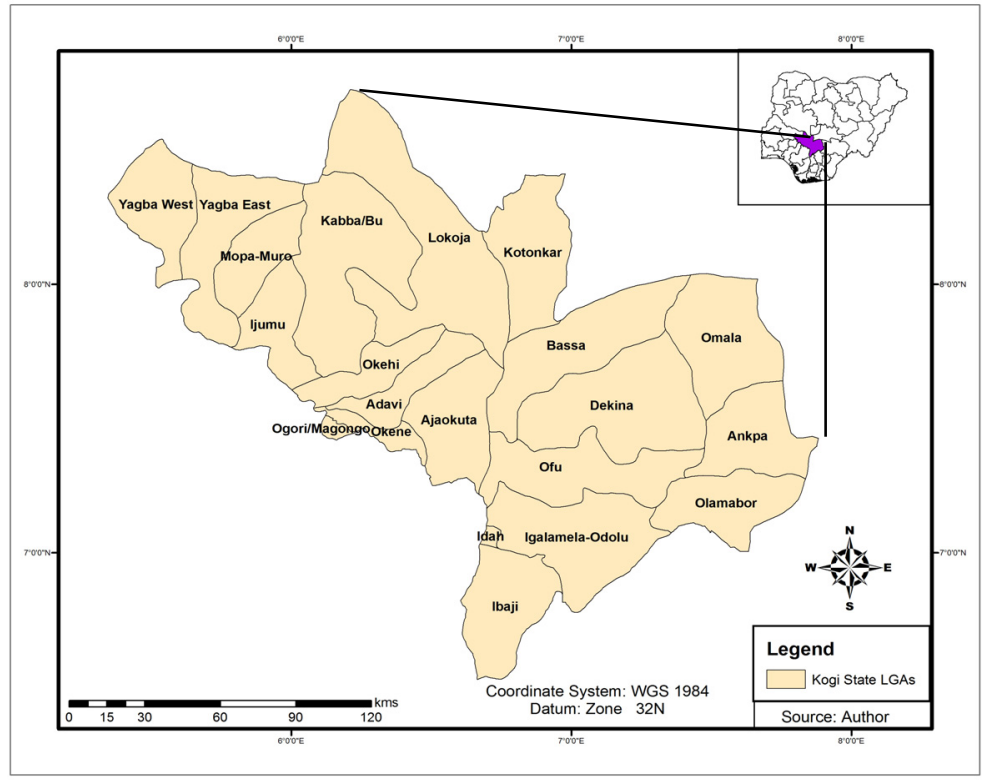

Figure 1: Study area map.

There are three main ethnic groups and languages in Kogi; Ighala, Ebira, and Okun. Kogi State has 21 local government areas. The state has an annual rainfall of between $1,100 \mathrm{~mm}$ and $1,300 \mathrm{~mm}$. The rainy season lasts from April to October and the dry season lasts from November to March. Agriculture is the main concern of the economy and principally cash crops. There are many farm produce from the state notably coffee, cocoa, palm oil, cashews, groundnuts, maize, cassava, yam, rice, melon. Mineral resources include; coal, limestone, iron, petroleum and tin.

\subsection{Ancestral beliefs and cultural norms of the flood plain residence}

In Kogi State, the people who reside in flood plain areas are usually low income earners whose socio-economic lives revolve around land and water due to the 
fact that they are predominantly farmers and fishermen. Most of the inhabitants of these flood plains can trace their history to the flood plains because there are lands that were inherited from their ancestors who lived, died and were buried on those lands. Also, natives of these flood plains are often connected to their environs in spiritual and ritualistic terms where soil, water, trees, animals etc. can be considered sacred [11]. Hence, sacrifice and ritual cleansing events are used to pacify and honour nature spirits and deity. It is also a belief by some culture that flooding is a blessing because it brings nutrients to their farmland. Flooding as severe as the 2012 flooding event had never occurred in their life time, and even it does, ancestral gods will intervene and ensure its impacts were neutralized. With this kind of customs and ancestral beliefs, it is believed that, the flood plain settlements are ancestral heritage; hence cannot be abandoned for fear of flood, as it may displease their ancestors.

\subsection{Poverty and Kogi State flood plain residence}

The world's economy in recent times is been faced by two challenges namely unemployment and poverty. The National Bureau of Statistics (NBS) in 2010 reported that the high incidence of unemployment amid economic growth is indicative of major socio-economic dislocations in the country. The economic situation in Nigeria experienced a decline due to the global fall in crude oil prices which has resulted to an increase in unemployment and poor standard of living. According to [12] in [13] graduate unemployment which was 26.6\% in 2003 rose to about $40.3 \%$ in 2009. Lack of employment opportunities and the consequential income disparity bring about mass poverty in most of the developing and under developed economies of the world [14]. With over 5 mineral resources present in Kogi State, it is surprising that the state is rated among the poor states in Nigeria. According to the press briefing on Nigeria Poverty Profile 2010 Report [15], Kogi State had 67.1\% as the absolutely poor while $32.9 \%$ as non poor amongst its populace. Hence, this has left the people no choice than to embark of their ancestral occupation (farming and fishing) as a source of livelihood rather than staying unemployed. The low salary scale with respect to the cost of goods and services in the state have made people to seek for cheaper accommodation in flood plain areas which is regarded as cheaper by one of the inhabitant of the flood plain area in order to shelter for their families.

\subsection{Municipal solid waste disposal and management in Kogi State}

In most developing countries, the problems associated with solid waste management are more acute than in the developed countries [16]. Furthermore, the increase of waste generation in the different regions of a country is indicative of its degree of urbanization [17]. Kogi State connects the northern, western and the eastern parts of Nigeria and consequently, it has led to an abrupt commercialization and urbanization of the state. The state also has a confluence the rivers Niger and Benue, and the Obajana cement factory which is assumed the largest in Africa has contributed to its urban and commercial development. The influx of goods and services, lifestyle and culture, and 
consumption pattern has contributed immensely to the increasing volume and variety of municipal solid waste in Kogi State. This has led to a serious environmental issue such that heaps of dumps are seen on open fields, roadside, and drainage systems which contribute to possible flood events in the state. Kogi waste management program was almost nonexistence because individual are solely responsible for the disposal of waste generated in their homes or institutions. This has left the state to no records or statistics on waste generation data, and management strategy. This grew as a concern such that in 2013, the governor of Kogi State signed into law the bill of establishment, functions and powers of the Kogi State Sanitation and Waste Management Board. This was imperative because the rate of indiscriminate dumping of solid waste was intolerable [18]. Figure 2 is the true pictorial evidence of the solid waste disposal pattern in Kogi environs.

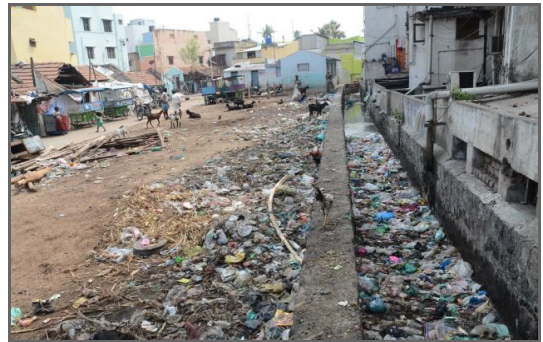

(a)

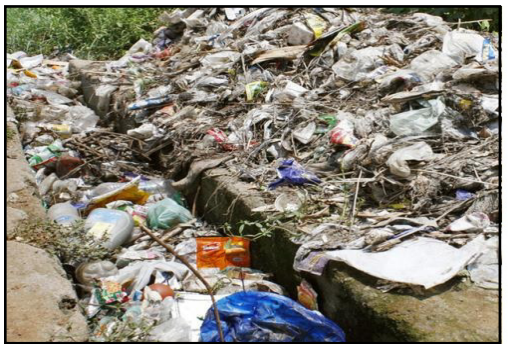

(b)

Figure 2: (a) Street dumping; (b) drainage dumping.

\section{Methods and materials}

This study used a Geographic Information System (GIS) approach to identify the communities residing in flood plain and also their vulnerability to possible flood event through geospatial analysis. Again, Aderoju Conceptual Model (ACM) for Sustainable Municipal Solid Waste Management was adopted as a method for educating the inhabitants of Kogi State in general on environmental ethics and discipline, waste management practices and solid waste management and its benefits. The conceptual model ACM is described with a schematic diagram in figure 6 .

\subsection{Data used and data source}

The data used for this study were obtained from both primary and secondary sources. The primary data sources are simply data obtained during the field survey while secondary data sources are data obtained from archive. The primary sources involved the use of Global Position Systems (GPS) receiver device to obtain the coordinates of affected communities in the study area. Also, photographs were taken with a digital camera during the field survey. The secondary data used includes the national river/water body map, settlement/road 
map and Kogi State map which was obtained from National Space Research and Development Agency (NASRDA) Abuja, Nigeria. The USGS Shuttle Radar Topography Mission (SRTM) data for Kogi State was also obtained from the Global Land Cover Facility (GLCF). The projection of the datasets was projected to World Geodetic System WGS 1984, Universal Transverse Mercator (UTM) Zone $32^{\circ} \mathrm{N}$. The GIS software, ArcGIS 9.3 was used to carry out the mapping and the geospatial analysis.

\section{Results and discussion}

\subsection{Geographic Information Systems (GIS) approach}

The Geographic Information Systems (GIS) was used to identify communities in flood plains zones in Kogi State and map out safe zones for the identified vulnerable communities to possible flood events. The results of the analysis in figure 4 shows the affected communities in Kogi State during the 2012 flood disaster event which was observed that 73 communities in 7 local government areas (Lokoja, Kotokarfi, Bassa, Ajaokuta, Ofu, Idah and Ibaji) are located flood plains. Figure 3 shows the Hydrology DEM of Kogi State based on the undulating mode of the terrain with different elevations. The hazard zones classification was done by a combination of both the Digital Elevation Model (DEM) and the contour value of Kogi State generated $100 \mathrm{~m}$ interval using the spatial Analyst extension of the ArcGIS 9.3 software.

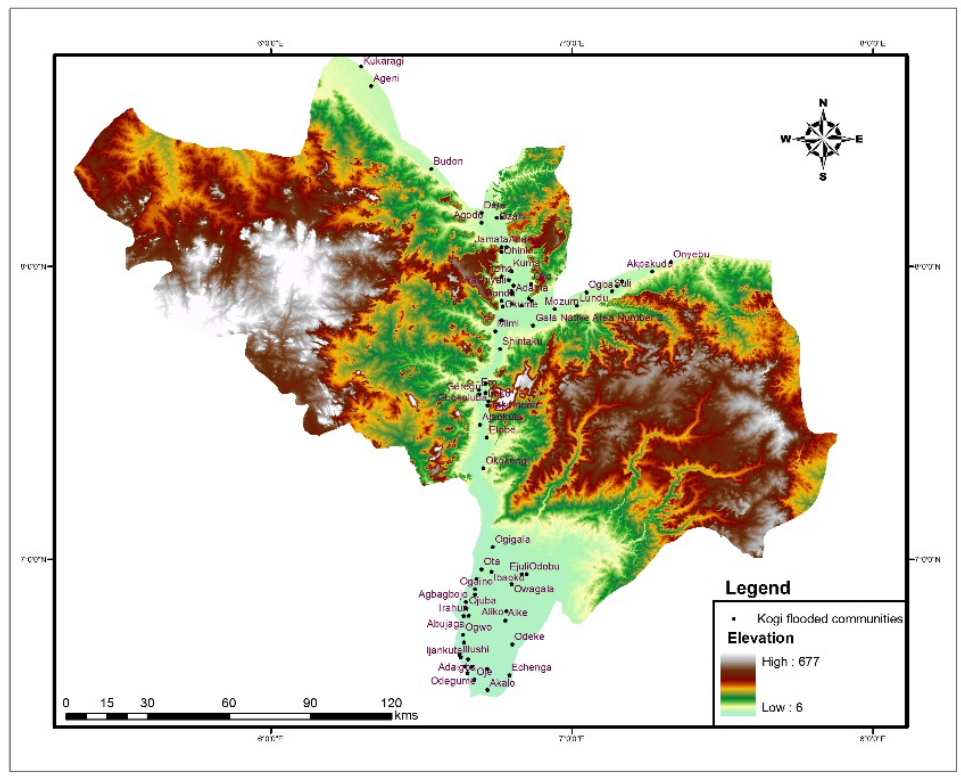

Figure 3: Kogi State Digital Elevation Model (DEM). 
Figure 4 shows the vulnerable communities to possible flood hazard in Kogi State. It shows the classification of the Kogi environs based on the elevation value of the terrain in 3 categories; highly vulnerable $(0-100 \mathrm{~m})$, moderately vulnerable $(101 \mathrm{~m}-200 \mathrm{~m})$ and safe zone $201 \mathrm{~m}$ and above.

Figure 5 shows the images of the 2012 flood events at Mimi community in Lokoja and Ota community in Ibaji, Kogi State.

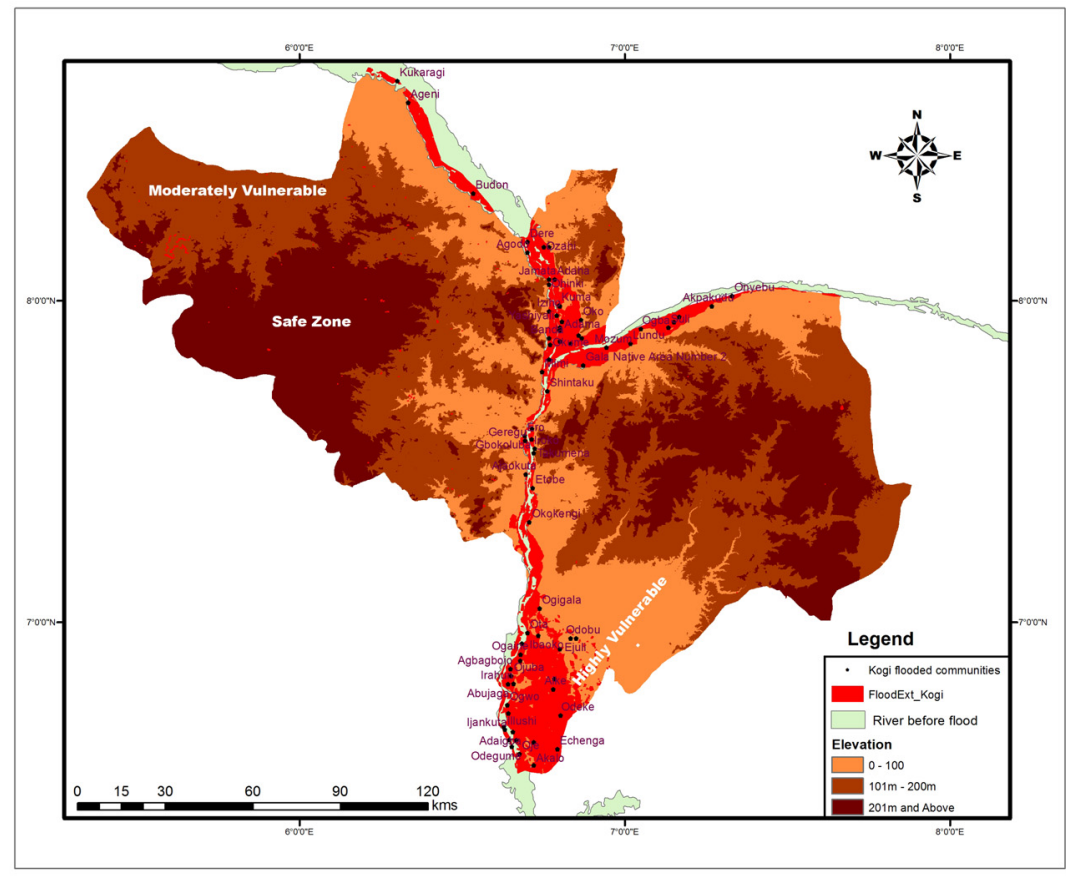

Figure 4: Flood vulnerability and hazard zoning map.

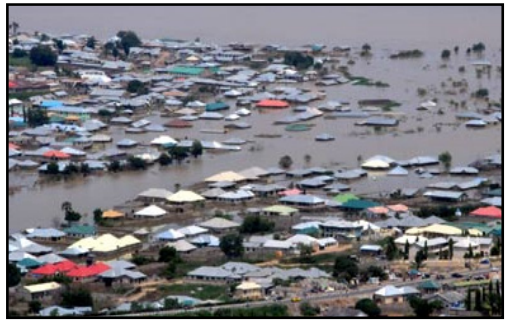

(a)

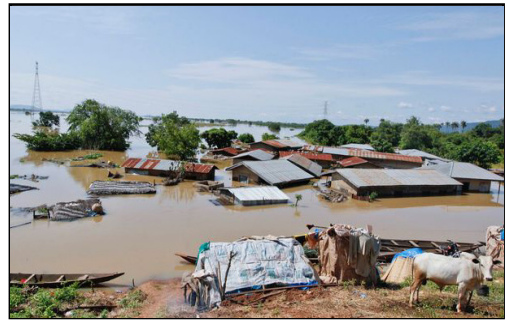

(b)

Figure 5: (a) Mimi community, Lokoja; (b) Ota community, Ibaji. 


\subsection{Aderoju Conceptual Model (ACM) for sustainable municipal solid waste management}

The ACM (see figure 6) is to change the attitude of the Nigerian people towards a sustainable waste management program. It is important to educate the people of Kogi State on the impact of waste dumping in open fields and drainage systems which contributes to flood hazard and possible the health risk to the society. In the light of this, the framework focuses on educating the people on environmental ethics and discipline, waste management practices and solid waste management and its benefits.

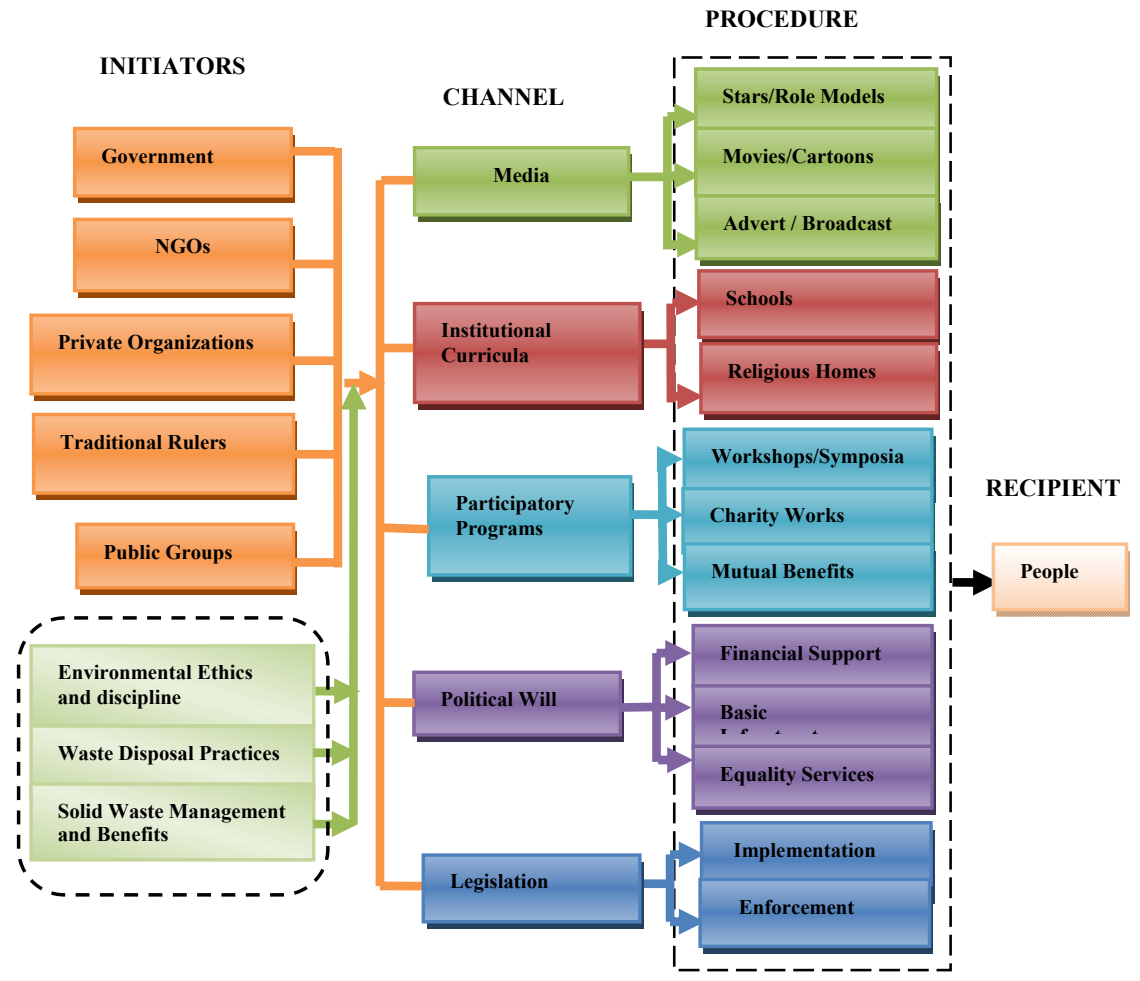

Figure 6: Concept of Waste Management Sensitization Program [19].

\subsection{Conceptual model discussion}

This model has 4 major stages namely; (initiators, channel, procedure and the recipient) with initiators as the principal actors of the model. Figure 6 describes the waste management sensitization program as follows; the initiators comprises of the government, NGOs, Private Organizations, traditional rulers as well as the public groups. The initiators carry out their responsibilities through a set of channel. The channel includes the media, institutional curricula, participatory programs, political will and legislation which convey its sensitization program 
through some procedure in order to reach the recipient. The channel functions as follows.

\subsubsection{Media}

The media is one of the best ways of reaching out to the people/public to pass on information because people spend much time using one form of the media service harnessing information and for pleasure. This is done using sport/movie stars and role models to educate people on environmental ethics and discipline on solid waste management through movies, television series, comedy shows, cartoons, animation, video games, social media, music and radio adverts and broadcast, billboards and many more.

\subsubsection{Institutional curricula}

This is another smart way of educating the kids, youths and adults in schools (elementary, high and tertiary), orphanage homes, and religion homes on environmental ethics and discipline regarding solid waste and more. This is simply because kids/youths believe strongly in their teachers and tend to reflect whatever they are taught in their daily lives. Again in religious homes, the fear and believe in the words of God has made people practice whatever that is taught for the benefit of man.

\subsubsection{Participatory program}

This involves incorporating the people of the society into the sensitization program from the start of the program/project which automatically craves their indulgence on the importance of solid waste management to their environment. In doing this, organizing workshop programs, symposia and talk show, charity work among the recipient (people) goes a long way educating them. Another aspect of this participatory program is the mutual benefit logic which involves companies recovering recyclables materials from homes through institutional arrangement. Schools instruct students to bring certain quantity of plastic bottles in from their homes which attract remuneration on the part of the schools and students.

\subsubsection{Political will}

The government should be committed to support on the campaign on solid waste management program by providing financial support, employ dedicated youths to educate the people, provide basis infrastructures and assure services provided would be of equal interest irrespective of the individual or set of elite.

\subsubsection{Legislation}

This is basically the implementation of existing environmental laws and its enforcement with respect to waste disposal and management. People should be aware of such laws and if defaulted, it attracts a heavy penalty like a monetary fine or jail term. 


\subsection{Recipient}

The people will be enlightened and refined because of a constant and continuous education and understanding on environmental discipline and solid waste management in general. With this model in place, the Nigerian people will adhere and adjust to the new environmental consciousness of the society. Since the youths of today are the ambassadors of the future, it is expected that environmental discipline, perception and attitude of Nigerians and the world at large on municipal solid waste disposal and management is passed unto the future generations.

\section{Conclusions and recommendation}

The study utilized GIS for the mapping and the analysis of the 2012 flood extent, the vulnerable areas and affected communities. Critical vulnerable and risk zones were clearly defined, and also the delineation of flooded areas. Another is the strong cultural affinity to flood plains as ancestral heritage of most affected communities and the high poverty level as a result of unemployment has led the people to seek for a cheaper shelter as well as a temporary source of income through fishing and farming. This did not help matters despite the prediction of the 2012 flood by Nigeria Meteorological Agency (NIMET) and the early warning pronouncement by National Emergency Management Agency (NEMA). Some of the inhabitants of the affected communities believed that flood is a blessing which brings fertility to their land and it will not be the reason to abandon their ancestral land leaving their ancestors graves on the land, their deity and most importantly their source of livelihood. Also it is imperative to enlighten the people of Kogi State on solid waste disposal ethics and discipline. With the Aderoju Conceptual Model (ACM) incorporated in the existing Kogi State solid waste management structure, a pollution free, safer and healthier living condition is guaranteed. The researcher therefore recommends that a comprehensive mapping and inventory of the entire flood plain of Kogi State and Nigeria as a whole should be embarked on for proper planning, sensitization programs for flood prone communities living in floodplain despite their ancestral beliefs. The government should work towards alleviating poverty by creating more employment opportunities for its people. Again, the government should ensure that an early warning system exist for the residence of the floodplain in order to alert them on when to evacuate to a safe zone during raining season. The sensitization programs should extended to rural areas and also be a continuous practice by all stakeholders in order to build a good and sustainable environmental ethics and discipline in waste disposal pattern amongst the people which can be passed unto the generations to come.

\section{Acknowledgements}

Our appreciation goes to National Space Research and Development Agency (NASRDA), Abuja for the provision of some data set and logistics for field 
survey. The researchers wish to express their appreciation to Head of Department, Geosciences, Environment and Spatial Planning, Faculty of Sciences, University of Porto, Portugal for his continuous support and encouragement.

\section{References}

[1] Few R., Ahern M., Matthies F. and Kovats S; Floods, health and climate change: a strategic review. Tyndall Centre for Climate Change Research, (63), 2004.

[2] International Federation of Red Cross and Red Crescent Societies (IFRC); "Nigeria: flooding in Kano and Jigawa", Information Bulletin No 2/01 (Final), available at http://www.ifrc.org/docs/appeals/rpts01/ngfl01a2.pdf, last assessed April 30 ${ }^{\text {th }}, 2015$.

[3] European Commission; "Directive 2007/60/EC of the European Parliament and of the Council of 23 October, 2007 on the Assessment and Management of Flood Risks", Official Journal of the European Union, L288/27-34, 2007.

[4] Jeb, D N and Aggarwal, S P; "Flood inundation hazard modeling of the River Kaduna using remote sensing and Geographic Information Systems", Journal of Applied Sciences Research, 4(12), pp. 1822-1833, 2008.

[5] Ojigi M.L, Abdulkadir, F.I and Aderoju, M.O; Geospatial Mapping and Analysis of the 2012 flooding Disaster in central parts of Nigeria; 8th GIS symposium, Dammaram, Saudi Arabia, April 15th-17th 2013.

[6] NEMA; Home, 2012, available at www.nema.gov.ng, last assessed May 3rd, 2015.

[7] Folorunsho R. and Awosika, L.F; Flood Mitigation in Lagos, Nigeria through Wise Management of Solid Waste: a case of Ikoyi and Victoria Islands; Nigerian, Paper presented at the UNESCO-CSI workshop, Maputo 19-23 November 2001.

[8] Ologunorisa T.E “An assessment of flood vulnerability zones in the Niger Delta, Nigeria”, International Journal of Environmental Studies, 61(1), pp. 31-38, 2004.

[9] Aderoju O.M, Eta J.B, Nwadike B.K, Ajonye S.E, Ihenacho N.M, Agu N.V, Eshiet R.I \& Mustapha S; Nigerian Satellites as an Option in Flood Disaster and Emergency Management. International Journal of Scientific \& Engineering Research, Volume 5, Issue 12, pp. 850-856, 2014.

[10] National Bureau of Statistics (NBS); Annual Abstract of Statistics, 2009. Available at www.nigerianstat.gov.ng, last assessed in April 30th, 2015.

[11] Snow K.H Encyclopedia of Religion and Nature, 2005. http://www.religionandnature.com/encyclopedia/index.htm. Last assessed April 30th, 2015.

[12] International Labour Organization (ILO); Labour force statistics, (2010).

[13] Nyong M.O; Unemployment Convergence among the 36 States in Nigeria; Finance and Economic Conference, Frankfurt, Germany, 2013. 
[14] EconomyWatch; Unemployment and Poverty, October 13, 2010.

[15] National Bureau of Statistics (NBS); Report of the national Bureau of Statistics Harmonized Nigeria Living Standard Survey (HNLSS), 2010.

[16] Zerbock O; Urban Solid Waste Management: Waste Reduction in Developing Nations, Michigan Technological University, 2003. Accessed Online May 3rd 2015. http://www.cee.mtu.edu/peacecorps/documents/ Waste_reduction_and_incineration

[17] Amalu T.U \& Ajake O.A; Appraisal of Solid Waste Management in Enugu City, Nigeria. Journal of Environmental and Earth Science Volume 4, No 1. pp. 97-105, 2014.

[18] Kogi Reports; Kogi State Sanitation and Waste Management Board's Scribe Commends Wada [Blog post], 13 ${ }^{\text {th }}$ August 2013. Retrieved from http://www.kogireports.com/kogi-state-sanitation-and-waste-managementboards-scribe-commends-wada/ assessed on the 14th July 2015.

[19] Aderoju O.M, Dias A.G \& Guimaraes R; Building Capacity an Integrated Perception and Attitude towards Municipal Solid Waste Management in Nigeria. WASTES: Solutions, Treatments and Opportunities, Published by Taylors and Francis Group, London, 2015. 